\title{
HUMAN ENTEROBIASIS IN EVOLUTION: ORIGIN, SPECIFICITY AND TRANSMISSION
}

\author{
HUGOT J.-P.*, REINHARD K.J.**, GARDNER S.L.*** \& MORAND S.****
}

\section{Summary :}

The co-evolutionary pathway seems to be the most plausible hypothesis for the explanation of the origin of human pinworms. Of the two modes of transmission of oxyurids among humans which have been documented, the direct oral/anal route is also observed in other Primates and seems to have been favoured by selection. As indirect air-borne transmission has also been shown for human enterobiasis, the question of "How this alternative to the standard transmission method could have arisen" is examined. The results of comparative studies of prevalence of Enterobius in human coprolites, in villages of Neolithic age of the arid west of North America, show that a higher prevalence of pinworms is correlated with the lower total amount of air-exchange in caves relative to other structures. The air-borne route of transmission of pinworms among humans is interpreted as an innovation in the human/Enterobius pair. This mode of transfer could have been favoured during the time when humans changed their behaviour from a hunting-gathering to a more sedentary existence, initially associated with cave habitats.

KEY WORDS : Enterobius vermicularis, E. gregorii, primates, pinworm, oxyurid, coevolution, enterobiasis, habitation, prevalence, dust, coprolites, air-bornecontagion, air as a vector, archaeological material, parasites, helminths, archeoparasitology.

MOTS CLÉS : Enterobius vermicularis, E. gregorii, primates, oxyures, coévolution, enterobiasis, habitations, prévalence, poussière, coprolites, transmission par voie aérienne, parasites, helminthes, paléoparasitologie.

\footnotetext{
* Muséum National d'Histoire Naturelle, Institut de Biosystématique (FR 1541 CNRS), Nématologie Fondamentale et Appliquée, 55, rue Buffon, 75231 Paris cedex 05, France; e-mail: hugot@cimrs1.mnhn.fr. ** Department of Anthropology, 126 Bessey Hall, University of Nebraska-Lincoln, Lincoln, NE 48588-0568, USA

${ }^{* * *}$ H.W. Manter Laboratory of Parasitology, W-529, University of Nebraska State Museum, University of Nebraska-Lincoln, Lincoln, NE 68588-0514, USA.

**** Centre de Biologie et d'Écologie Tropicale et Méditerranéenne, Laboratoire de Biologie Animale (UMR 5555 CNRS), Université de Perpignan, Av. Villeneuve, 66860 Perpignan, France.

Correspondence: J.P. Hugot.
}

Résumé : HYPOTHÈSES SUR L'ORIGINE ET LA SPÉCIFICITÉ DES OXYURES HUMAINS : LIENS AVEC LEUR MODE DE TRANSMISSION

Deux modes de contamination ont été reconnus dans l'enterobiasis humaine: la voie oro-anale, également connue chez d'autres primates, et la voie aérienne dans laquelle des œufs en suspension dans l'air sont inhalés puis déglutis. Les études de cophylogénie ont d'autre part révélé l'existence d'un parallélisme si marqué entre l'arbre évolutif des Primates et celui de leurs oxyures, qu'il ne peut être expliqué que comme le résultat d'un phénomène d'étroite coévolution. Les oxyures humains sont donc probablement les descendants des parasites des ancêtres primates de l'Homme, régulièrement transmis de génération en génération. Or, si l'on distingue aisément pourquoi la voie oro-anale a été favorisée par la sélection chez des animaux nomades et vivants dans des milieux arborés ou de savane, l'efficacité de la transmission par voie aérienne est probablement faible dans ces mêmes milieux. Les résultats de l'étude comparative de la prévalence des œufs d'oxyures humains dans des séries de coprolites collectés sur plusieurs sites néolithiques du sud-ouest des Etats-Unis permettent de tenter d'expliquer comment ce mode de contamination a pu être favorisé. On observe en effet que la prévalence des œuts est beaucoup plus élevée sur les sites anciennement occupés par des agriculteurs vivants dans des villages, que sur ceux occupés par des chasseurs-cueilleurs ou des agriculteurs nomades. De plus, lorsque l'on compare les prévalences respectives de villageois vivants, soit dans des maisons construites en milieu ouvert, soit dans des maisons troglodytes, on observe à nouveau une différence significative : le taux d'oxyurose est environ deux fois plus important à proximité des habitations construites au flanc des falaises et utilisant en partie des cavités naturelles de la roche. II semble donc que l'augmentation de la densité des populations humaines et les modifications de leur régime alimentaire qui ont accompagné le développement de l'agriculture ne puissent expliquer totalement ce phénomène, et que les différences observées puissent être en partie liées au type d'habitat. L'interprétation que nous proposons à partir de ces différentes observations est la suivante : la transmission par voie aérienne ne peut être efficace que dans un milieu confiné où les courants d'air sont faibles, comme l'est l'atmosphère des grottes ou des abris aménagés sous roche, qui partout ont été utilisés au cours du développement des sociétés humaines; nous faisons l'hypothèse que le mode de transmission par voie aérienne a pu être progressivement favorisé au cours de ces périodes, de telle sorte que dans les circonstances où une augmentation importante de la densité des populations s'est accompagné de l'occupation d'un habitat particulièrement propice à la transmission par voie aérienne, l'ensemble de ces facteurs ait contribué à augmenter de façon considérable le taux de contamination des groupes concernés 


\section{INTRODUCTION}

$A$ shford \& Crewe (1998) noticed that, of the 399 species of parasites that have been reported from humans, more than $70 \%$ are "adventitious" species for which man is an incidental host and only $16 \%$ can be considered "core" species, dependent on man for their survival. Ashford (1991) also illustrated how parasites may become parasitic in humans by either host-transfer or coevolutionary pathways. Combes (1990) had observed this previously and considered that most parasites of humans originally transferred to man from non-primate hosts. $\mathrm{He}$ explained this as a consequence of the ecological characteristics of humans. Because of our tendency to inhabit extremely varied environments and because of varied behavioural patterns exhibited by humans, we provide myriad opportunities for parasites to occupy new hosts. In other words, when humans left the natural habitat of their primate ancestors and progressively conquered all available geographical ranges on Earth, they also penetrated the territory of different parasites of which some host-switched successfully, adapted, and speciated, becoming host-specific human parasites.

Here we investigate the origins of human pinworms and the reasons which can explain their high specificity. This leads us to examine and compare the ways of transmission of the pinworm parasites in different host groups. For many years the literature on pinworm ecology has recognised the importance of oral ingestion as the primary means of perpetuating infections of these nematodes within and between human hosts. However, recent work suggests that air-borne transmission of pinworm eggs may also be important in maintenance of their life-cycle. Air-borne transmission of pinworms among modern humans is discussed relative to the accumulating data sets on the prevalence of parasites in coprolites from Neolithic humans.

\section{MATERIALS AND METHOD}

A sample of 830 coprolites from the arid areas of North America allows to consider Enterobius vermicularis infection in context with changing habitation patterns. Table I summarises the dates for most of the locations in which positive coprolites have been discovered. The larger number of dates in the $\mathrm{AD}$ range does not reflect more sites studied from later time periods. It simply indicates that pinworm eggs are more commonly found at later sites. Table II presents the locations which were investigated for human coprolites, ordered by habitation type, and

\begin{tabular}{ll}
\hline \multicolumn{1}{c}{ Date } & \multicolumn{1}{c}{ Locality } \\
\hline 8,000 BC & Danger Cave, Utha \\
$4,800-4,300 \mathrm{BC}$ & Dirty Shame Shelter, Oregon \\
$4,010-650 \mathrm{BC}$ & Hogup Cave, Utah \\
AD 400 & Turkey Pen Cave, Utah \\
AD 600 & Antelope House, Arizona \\
AD 500-1,200 & Clyde's Cavern, Utah \\
AD 920-1,130 & Pueblo Bonito, New Mexico \\
AD 1,075-1,140 & Antelope House, Arizona \\
AD $1,100-1,250$ & Salmon Ruin, New Mexico \\
AD $1,250-1,300$ & Inscription House, Arizona \\
\hline
\end{tabular}

Table I. - Dates for Enterobius vermicularis finds from North America.

tabulates the prevalence of E. vermicularis eggs. Hunter-gatherer sites were occupied by small groups of people (less than 50) who subsisted on wild plants and animals. Agricultural sites were occupied by large groups of people (several hundred) who subsisted in part on cultivated plants and in part on wild plants and animals.

Parasite remains have been recovered from coprolites (desiccated faeces) for 2.5 decades in North America (for review see Reinhard, 1990). Paleoparasitological methodology was established by Samuels (1965) when he developed the rehydration and sedimentation technique for extracting parasite eggs from coprolites. Since that time, relatively little variation has occurred other than the introduction of new equipment and adaptation to available materials. Consistency in technique is essential for comparing data collected by several researchers over a 25 -year period: the fact that the technique of Samuels (1965) was followed with minor variations by all North American coprolite researchers until present supports the validity of comparative analysis. To further evaluate the consistency of results, Reinhard (1988) analysed coprolites from Antelope House, one of Fry's main study sites. No statistical difference in recovery of eggs of E. vermicularis or larvae was found. Therefore, we believe that, with regard to E. vermicularis, the data sets from different researchers may reliably be compared.

Relative preservation of the remains between sites is also a significant factor when considering the reliability of intersite comparisons. In the case of these coprolites, the eggs show excellent preservation, except for those from Pueblo Bonito which were poorly preserved. For the rest of the sites, the eggs were well preserved and the larvae were sufficiently robust to allow them to be squeezed out of the egg. However, even for the site which exhibited relative poor preservation, the eggs were still recognisable and identifiable. 


\begin{tabular}{|c|c|c|c|}
\hline Studied & Positive & Site & Analyst \\
\hline & & \multicolumn{2}{|l|}{ Cave Dwelling, Hunter gatherer } \\
\hline 100 & 0 & Dust Devil Cave & Reinhard \\
\hline 50 & 0 & Love Lock Cave & Heizer and Napton \\
\hline 46 & 1 & Danger Cave & Fry \\
\hline 50 & 4 & Hogup Cave & Fry \\
\hline 32 & 0 & Frightful Cave, Coahuita, Mexico & Fry \\
\hline 13 & 1 & Dirty Shame Rock Shelter & Hall \\
\hline 35 & 0 & Bighorn Cave & Reinhard \\
\hline 326 & $6(1.8 \%)$ & & \\
\hline & & \multicolumn{2}{|l|}{ Cave sites without stone walled villages/Agricultural } \\
\hline 30 & 0 & Glen Canyon Anasazi & Fry \\
\hline 10 & 0 & Glen Canyon Fremont & Fry \\
\hline 40 & $0(0 \%)$ & & \\
\hline & & \multicolumn{2}{|l|}{ Stone walled Villages/Agricultural } \\
\hline 112 & 9 & Salmon Ruin & Reinhard \\
\hline 5 & 0 & Kin Ketso & Reinhard \\
\hline 15 & 4 & Pueblo Bonito & Reinhard \\
\hline 132 & $13(9.9 \%)$ & & \\
\hline & & \multicolumn{2}{|l|}{ Stone walled Villages in Caves/Agricultural } \\
\hline 180 & 44 & Antelope House & Reinhard \\
\hline 20 & 2 & Bighorn Sheep Ruin & Gardner \\
\hline 56 & 4 & Hoy House & Stiger \\
\hline 17 & 3 & Inscription House & Fry \\
\hline 20 & 1 & Step House & Samuels \\
\hline 283 & $54(19 \%)$ & \multirow{2}{*}{\multicolumn{2}{|c|}{ Unknown Construction in Caves/Agricultural }} \\
\hline & & & \\
\hline 24 & 7 & Turkey Pen Cave & Reinhard \\
\hline 25 & 4 & Clydes Cavern & Hall \\
\hline 49 & $11(22 \%)$ & & \\
\hline
\end{tabular}

Table II. - Tabulations of Enterobius vermicularis finds by habitation and subsistence type.

As in the following we use the prevalence of Enterobius eggs in stools as an indicator of the prevalence of infection, the question arises of how both indices are related. Frequently Enterobius eggs prevalence in stools is relatively low as compared with the prevalence of other helminth eggs (Chieffi et al., 1974; Haswell-Elkins et al., 1987). This can be considered a consequence of the peculiar behaviour of female pinworms which release their eggs outside where they get stuck around the anus. This also explains that the prevalence of Enterobius eggs in stool samples is generally highly inferior to the rate of infested individuals in the same population. Another characteristic of pinworm infections is that a great amount of the worms are aggregated in a small fraction of the population and that certain households contain aggregations of heavily infected individuals (Haswell-Elkins et al., 1987; Hugot, unpublished). This suggests that when considering egg prevalence in stools we are probably underestimating the prevalence of infection, not the contrary.

Archaeological results are only as useful as dating procedures are accurate. In the case of the coprolite data, dating the coprolites is based on stratigraphic association, radiocarbon analysis, and dendrochronological dates.

\section{RESULTS}

The lowest prevalence of E. vermicularis is observed at hunter-gatherer cave sites (2\%) and in agricultural peoples living without stone

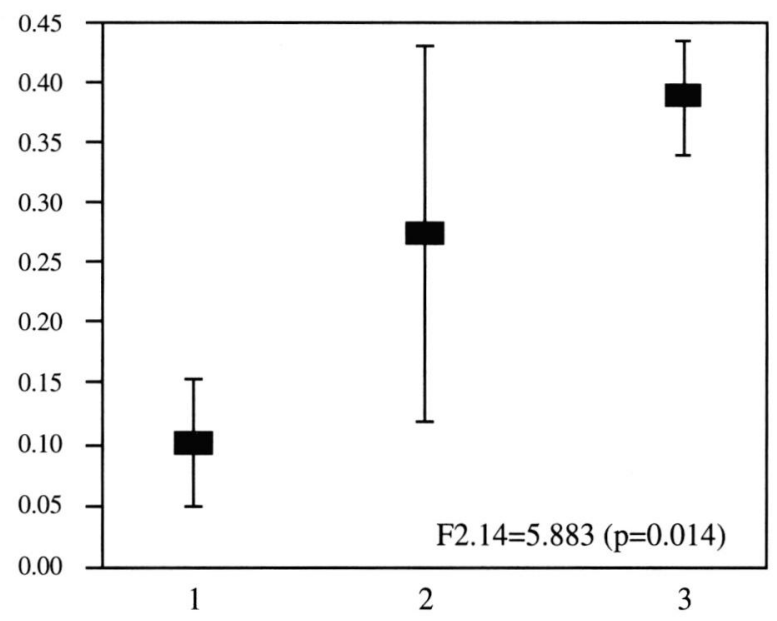

Fig. 1. - Result of an ANOVA performed on eggs prevalence values, transformed in arsinus (prevalence ${ }^{1 / 2}$ ) in order to normalise residuals (Zar, 1984). 1: cave dwelling hunter gatherer; 2: stonewalled villages agricultural; 3: stonewalled villages or unknown constructions in caves, agricultural. 
walled villages $(0 \%)$; the latter sites have maize and other domesticated crops but lack villages. Stone walled agricultural villages not associated with caves have a prevalence of $10 \%$. The highest prevalences (19 \% and $22 \%$ ) are observed among coprolites of agricultural peoples living in villages or constructions in caves. ANOVA (Fig. 1) revealed a significant influence of habitat/subsistence types on prevalence of eggs $(P=0.014)$. However, only egg prevalence in cave dwelling hunter/gatherer was significantly lower than egg prevalence in agricultural caves (Scheffe's post hoc test, $\mathrm{P}<0.014$ ).

\section{DISCUSSION}

\section{HOST-TRANSFER OR COEVOLUTIONARY PATHWAY?}

$\mathrm{P}$ inworms occur in most families and genera of the order Primates. Host specificity is extreme in the pinworms, with each species of nematode occurring in a specific host (Hugot, Gardner \& Morand,
1996). Cameron (1929) first suggested a close correspondence between phylogenetic histories of both Oxyurids and Primates: "The examination of the forms ... (of pinworms found in Primates) ... suggests ... that the parasite has evolved with the host. If one assumes the existence of a pre-enterobius form in the pre-simian host, then the modifications of the parasite should accompany the generic difference of the host. One will expect to find forms more closely related to the human parasite in apes, while those in old World monkeys would be closer to E. vermicularis than those in new World monkeys and the lorises but not so close as in apes". Later, Sandosham (1950) and Inglis (1961), and finally Brooks \& Glen (1982) using cladistic analysis, gave additional arguments for coevolutionary relationships among Primates and their oxyurid parasites. Recently, because they share derived characters, most members of the Oxyuridae Cobbold, 1864, parasitic in Primates have been grouped into a new subfamily: the Enterobiinae Hugot, Gardner \& Morand, 1996. The results of a cladistic analysis of the Enterobiinae (Hugot, in press) extensively supports the hypothesis

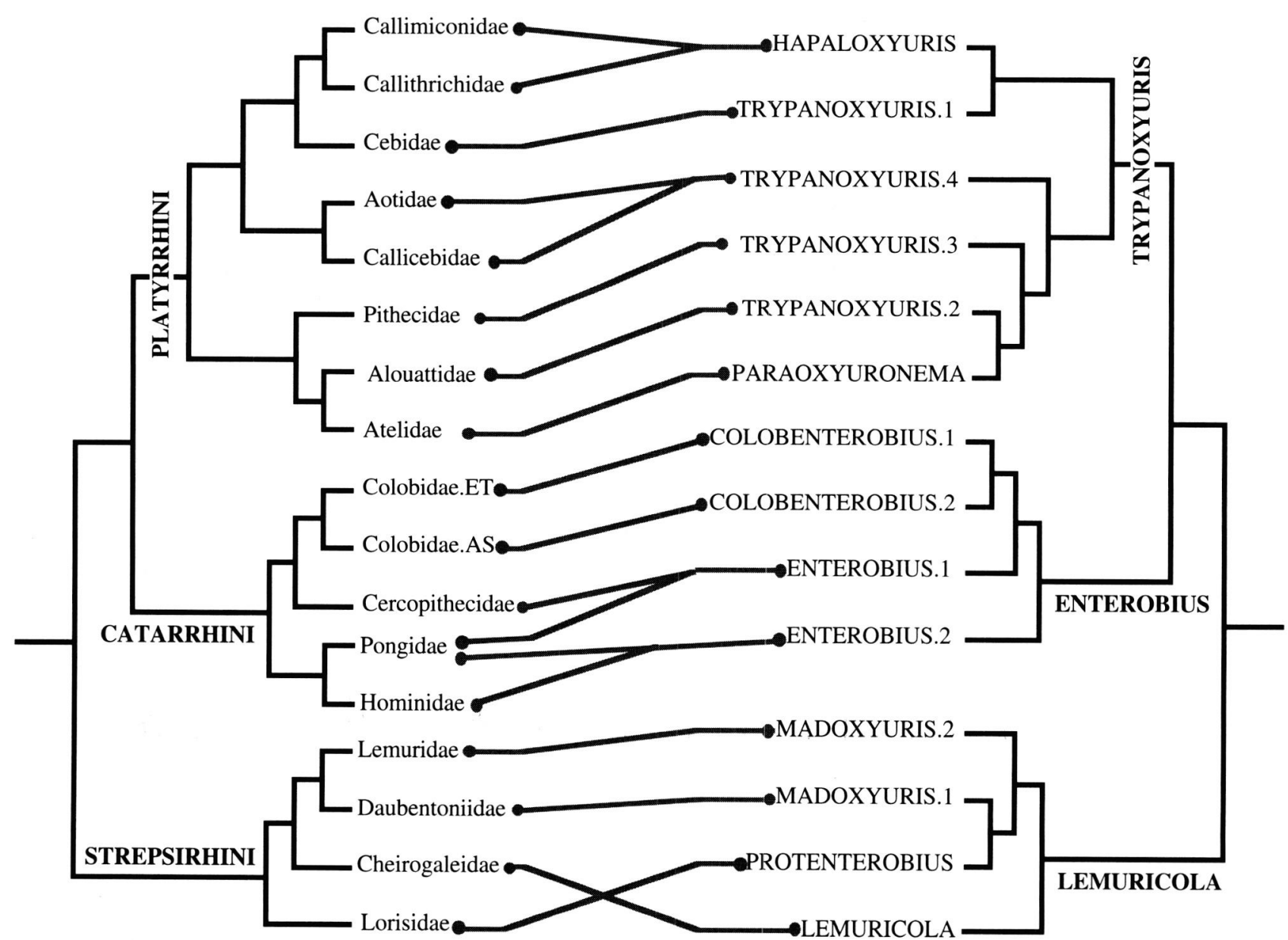

Fig. 2. - Tree reconciliation "parasite clades versus host families". Host tree after Purvis (1995) modified. Parasite tree after Hugot (in press) $\mathrm{ET}=$ Ethiopian; $\mathrm{AS}=$ Asiatic. 
of Cameron in its aspect of "coevolution + cospeciation" or "association by descent" as defined by Brooks \& McLennan (1991). As expected by Cameron (1929), the closest relative to the human parasites, Enterobius vermicularis (Linneus, 1758) and E. gregorii Hugot, 1983, is the parasite of the chimpanzees: E. anthropopitheci Gedoelst, 1916. The sister-group for these three species includes the parasites of the apes (orang-utan and gorilla), and old World monkeys (baboons, macaques and guenons). A tree reconciliation "parasite species versus host species" performed using TreeMap (Page, 1995) gave $64 \%$ of codivergence (superimposable nodes) between the trees; however, when considered at the level of "parasite clades vs. host families" the congruence extended to $84 \%$ of superimposable nodes (Fig. 2). The probability for such a high percentage to occur by chance, as revealed by a Markovian test, is $p=0.001$. Thus the co-evolutionary pathway seems to be the most plausible hypothesis for explanation of the origin of human pinworms

Cameron (1929) asked the question: "why and how such a high specificity?" and he speculated that "the life history of primate pinworms tends to make them parasites of the individual because ... their eggs do not tend to be broadcast as do those of other helminthes..." This can probably be extended to the whole order Oxyurida in which Maupas \& Seurat (1916) and Seurat (1916, 1920) demonstrated that the infestive larval stages (L3) develop within the egg, which makes these larvae unable to actively search for a new host. In addition, most of the oxyurids parasitic in mammals have their eggs either grouped into a pouch as the parasite of domestic rabbits (Hugot, Bain \& Cassone, 1982), stuck together with an adhesive secretion of the female as the oxyurids of the porcupines (Hugot, 1982), or they occasionally stay enclosed inside the female cuticle after its death (Seurat, 1916). This nondissemination of the eggs reduces the chances for a new host to be infected and transmission may be assisted by a special behaviour.

\section{CAECOTROPHY AND PINWORM TRANSMISSION}

In the Rodentia and Lagomorpha, infestation is probably facilitated by both grooming and caecotrophy (sensu Morot, 1882 = pseudo rumination sensu Taylor, 1940): during intervals of resting, the animals produce special droppings (the caecotrophs, after Morot, 1882). They swallow these small faeces pellets by arching their back until they are able to collect them up at the time they are discharged by the anus. This special behaviour was first described from the Lagomorpha and has been later recorded in most families of Rodent (Kenagy \& Hoyt, 1980). It is interpreted as a way for recycling cellulose after it has been transformed into sugars by bacteria and protistans living in the caecum. This is also a very efficient way for the packaged and non-invasive parasite eggs to be ingested. In humans and other Primates, swallowing eggs implies different mechanisms.

\section{THE ANAL CONNECTION}

Descriptions of enterobiasis as reported by Moulé (1911) prove that the ancient Greeks and Latins already had recognised human pinworms and discovered pregnant female nematodes crawling around the anogenital area during the night. Nocturnal egg-laying accompanied by a strong pruritus is common in enterobiasis. This explains why anal swabs remain the best and simplest way for diagnostic. This also explains why pinworm eggs have such a high prevalence on children's hands and fingernails (Chieffi et al., 1974; Ryang, 1975). This method of transmission has also been observed in other Primates and is likely to be a common trait for the whole order.

\section{THE AIR-BORNE CONNECTION}

Another method of transmission is suggested for human enterobiasis. When sampling house dust, furniture, bed-clothes, etc., in schools, nurseries and orphanages, Enterobius eggs were encountered everywhere (Nolan \& Reardon, 1939; Gieryng \& Pietron, 1981) and were more frequent than eggs of other parasites such as Trichuris, Ascaris and Taenia (Chieffi et al., 1974; Chung, Chang \& Horng, 1978; Engelbrecht $\&$ Berendt, 1991). These authors also observed that the larger the space for children's activity, the lower the prevalence of eggs. This relationship between air volume, space, and abundance of eggs was also reported by Engelbrecht \& Berendt (1991). In addition, Irgashev, Babaeva \& Daidaliev (1974) and Babaeva \& Saidaliev (1975) observed that: "All dust samples taken from the bedding and flooring of houses in a hamlet near Samarkand, Uzbek SSR, contained Enterobius ova and occasionally ascarid and taeniid eggs. Of the many thousands of Enterobius ova collected, between $\mathbf{6 5 . 5}$ and $85.5 \%$ were viable. The average number of ova/g of dust was 7.7 to 13.1" (our emphasis). These reports clearly show that Enterobius eggs can reach a high prevalence in air and dust in human environments and that a great number of those floating eggs remain viable or infective. This show that, in particular conditions, air-borne transmission can be considered an alternative to oral infestation for human enterobiasis (Smyth, 1994).

\section{SPECIFICITY AND MECHANISMS OF TRANSMISSION}

The Oxyurida are unique among the parasitic forms in the Nematoda being the only group that was able to colonise and undergo a spectacular diversification 
in both invertebrates (cockroaches and millipedes principally) and vertebrates. In mammals, the Oxyurida succeeded primarily in the Primates, Rodentia, and Lagomorpha in which every host genus (and in some cases every host species) has its specific pinworm. The gregarious and sedentary life history of the invertebrate hosts of the Oxyurida explains that new hosts could easily be infected with eggs and coprophagy is probably an important method of transmission in these hosts. In mammals the mechanisms described above result in a very short or almost non-existent free living stage for the parasite. For this reason and because interspecific interactions are rare, a close correspondence between phylogenetic histories of the oxyurids and their specific hosts can be observed. With nonsedentary hosts such as Primates, it is easy to understand that the "anal/oral connection" may be appropriate, and then favoured by selection since Primates and their pinworms are living close together. Conversely the "air-borne connection" appears as an inefficient method of transmission among wandering hosts, living either on trees, or in open savannas. Thus a question must be asked: How this alternative to the standard way of transmission could arise? The discovery of various different levels of prevalence of Enterobius eggs in human coprolites from Northern America allows speculation on how air-borne transmission can influence the prevalence of enterobiasis.

\section{VISITING "UNHEALTHY" CAVES}

The earliest discovery of E. vermicularis is from Danger Cave, Utah, deposited about 8,000 years ago and the dates for the later sites are in the thirteenth century AD: before Europeans invaders first arrived in America. These ancient dates suggest that E. vermicularis entered the Americas with the first migrations of humans and was not introduced later with transoceanic contact. Therefore, the parasite has great antiquity in the New World and the variation in prevalence of E. vermicularis through time is not a result of recent introductions, but rather of behavioural characteristics of indigenous peoples.

It is apparent that two aspects of human behaviour affect the prevalence of $E$. vermicularis in humans, including: subsistence type and dwelling type. These two aspects are not independent; hunter-gathering subsistence limits numerical group size of populations to no more than about 50 people. Especially in arid lands, carrying capacity prevents the development of large numbers of hunter-gatherers. Also, because hunter-gatherers must frequently move from one area to another to find food, the development of permanent structures among such cultures is unknown and these factors ultimately define the nature of huntergatherer parasitism (Reinhardt, 1988). The development of agriculture had significant impacts on habitation type and numerical density of populations. A dependable, storable food supply led to the increase of populations such that hundreds to thousands of people lived together. The need to store food, and need to defend arable land, necessitated the establishment of permanent villages. These aspects of agricultural life led to an impressive change in the nature of human parasitism as documented by studies of coprolites (Reinhard, 1988). In the arid west of North America, many of the permanent villages were established in caves, often as a defensive. measure. Each of these stone walled villages (Salmon Ruin, Kin Kletso, and Pueblo Bonito), is a large, multi-storied complex containing between 200 and 500 rooms. They represent the largest villages built in the Southwest before $1300 \mathrm{AD}$.

Thus, the increase in pinworm prevalence in coprolites as compared to agricultural people and hunter gatherers may be presumed to be related to numerical density of the human population, due to the increased probability of transmission of pinworms in larger populations. However: $i$ ) the results of investigations in Glen Canyon (Table I) suggest that pinworm prevalence among agricultural peoples was not greater than huntergatherers, if agriculturists did not live in village or constructions, ii) there is also a remarkable increase in pinworm positive coprolites in villages within caves. Point $i$ ) suggests that diet alone did not affect prevalence. Analyses of room patterns between cave villages and open villages suggest that the basic organisation of open villages was the same as in caves. This means that it is unlikely that populations of humans were larger or more concentrated in caves. Thus, point $i$ ) indicates that numerical density of the population is not the only variable that led to increased pinworm infection. Therefore, there must be some other factor involved.

One distinct difference between caves and open villages is the fact that air flow is limited within the confines of a cave. This allows air-borne particles to remain in the air column for a longer period of time which in turn increases the probability that humans living in the cave will encounter these particles. It has been shown that E. vermicularis eggs are infective via inhalation and may abound in the air environment of humans when living in confined and sedentary habitats. Therefore, the still air of caves enhances the potential for human infection with pinworms. Thus, for agriculturists who built their villages in caves, the interplay of larger population combined with the reduced air circulation in caves may explain the remarkable increase of $E$. vermicularis infection which is reflected by greater numbers of coprolites that are positive for eggs.

In conclusion, the oral/anal mode of transmission which results in a very short or almost non-existent free 
living stage for the parasite allowed the Primates and their pinworm parasites to live an "idyllic and uninterrupted romance", probably from the time of origin of the hosts themselves. As the air-borne transmission cannot reliably be considered advantageous for transmission among wandering hosts, living either on trees, or in open savannas, as were the primate ancestors of humans, we argue that this different mode of transmission could be an innovation of the human/Enterobius pair. This different mode of transfer could have been favoured during the time when humans became more sedentary, which initially associated with cave habitats. In addition, during humans progressively settled and developed denser populations they also acquired a more and more sophisticated language which tended to substitute for grooming. This in turn could result in a reduction of body contacts and a decreasing efficiency of the oro/anal mode of transmission.

However, some questions remain which presently we are unable to response. First, did the capacity for eggs to float in air and to remain viable and infective appear in the human/Enterobius pair, or, is this method of transmission potentially available to other related species, but reveals to be inefficient due to the different way of life of the hosts? Solely experimental investigations could evidence if other Enterobius eggs can be transmitted in air and if human forms resist desiccation better. As the parasites of man are considered to be two different species (Hugot, 1983), another interesting question would be to determine if any special adaptation for air-borne transmission developed either in Enterobius vermicularis or E. gregorii.

\section{REFERENCES}

ASHFORD R.W. The human parasite fauna: towards an analysis and interpretation. Annals of Tropical Medicine and Parasitology, 1991, 85, 189-198.

ASHFORD R.W. \& CREW W. The parasites of Homo sapiens: an annotated checklist of the protozoa, helminths and arthropods for which we are home. Liverpool: Liverpool School of Tropical Medicine, 1998, 128 p.

BabaEVA R.I. \& SAIDALIEv T. Survival times of Enterobius ova on household items. Aktual'nye Problemy Meditsinskoi Parazitologii, 1975, 2, 82-84.

Brooks D.R. \& GLEN D.R. Pinworms and primates: a case study in coevolution. Proceedings of the Helminthological Society of Washington, 1982, 49, 76-85.

Brooks D.R. \& McLennan D.A. Phylogeny, ecology and behaviour. Chicago Univ. Press, Chicago, 1991, 434 p.

Cameron T.W. The species of Enterobius Leach, in Primates. Journal of Helminthology, 1929, 7, 161-182.

Combes C. Where do human parasites come from? Annales de Parasitologie Humaine et Comparée, 1990, 65, 59-64.
Chieffi P.P., Moretti I.G., Foizer A.C.M., Nakagawa E. \& Gomes A.C Studies on the epidemiology of enteroparasitoses in a closed population. II. Mechanisms of transmission. Revista da Sociedade Brasileira de Medicina Tropical, $1974,8,87-91$.

Chung W.C., Chang K.C \& Horng S.H. Epidemiology of Enterobius vermicularis infection among orphans in orphanages in Taipei City. Chinese Journal of Microbiology, 1978, 11, 30-36.

ENGELBRECHT H. \& BeRENDT H. Investigation of house dust for eggs of Enterobius vermicularis. I. Methods. Angewandte Parasitologie, 1991, 32, 15-19.

Gedoelst L. Notes sur la faune parasitaire du Congo Belge. Revue de Zoologie Africaine, 1916, 5, 24-27.

GIERYNG R. \& PIETRON W. Detection of the eggs of parasitic nematodes in the rural environment by the method of Kaledin and Romanienko. Wiadomosci Parazytologiczne, 1981, 27, 591-597.

Haswell-Elkins M.R., Elikins D.B., Manjula K., Michael E. \& ANDERSON R.M. The distribution and abundance of Enterobius vermicularis in a South Indian fishing community. Parasitology, 1987, 95, 339-354.

Hugot J.P. Sur le genre Wellcomia (Oxyuridae, Nematoda), parasite de Rongeurs archaïques. Bulletin du Muséum National d'Histoire Naturelle, Paris, 1982, 4, 25-48.

Hugot J.P. Enterobius gregorii (Oxyuridae, Nematoda), un nouveau parasite humain (Note préliminaire). Annales de Parasitologie Humaine et Comparée, 1983, 58, 403404.

HugOT J.P. Primates and their pinworm parasites: the Cameron hypothesis revisited Systematic Biology, 1999, 48, (in press).

Hugot J.P., Bain O. \& Cassone J. Insémination traumatique et tube de ponte chez l'oxyure parasite du lapin domestique. Comptes-rendus de l'Académie des Sciences, Paris, 1982, 294, 707-710.

Hugot J.P., Gardner S.L. \& Morand S. The Enterobiinae fam. nov. (Nematoda, Oxyurida), parasites of Primates and Rodents. International Journal for Parasitology, 1996, 26, 147-159.

INGLIS W.G. The oxyurids parasites (Nematoda) of Primates. Proceedings of the Zoological Society, London, 1961, 136, 103-122.

IRgaShev I.K.H., BaBAEVA R.I. \& Daidaliev T. The survival of Enterobius ova in dust. Trudy Uzbekskogo Nauchno Issledovatel'skogo Veterinarnogo, 1974, 22, 38-40.

Kenagy G.J. \& Hoyt D.F. Reingestion of feces in rodents and its daily rhythmicity. Oecologia, 1980, 44, 403-409.

Maupas E. \& Seurat L.G. Sur les mécanismes de l'accouplement chez les Nématodes. Comptes-rendus des Séances de la Société de Biologie, Paris, 1916, 79, 607-611.

Morot C. Des pelotes stomacales des Léporidés. Mémoires de la Société centrale de Médecine vétérinaire, 12, sér. 1, Paris, 1882.

Moulé L. La Parasitologie dans la littérature antique. II. Les parasites du tube digestif. Archives de Parasitologie, 1911, 15, 353-383. 
NOLAN M. \& REARDON L. Distribution of the ova of Enterobius vermicularis in household dust. Journal of Parasito$\log$, 1939, 25, 173-177.

PAGE R.D. Parallel phylogenies: reconstructing the history of host-parasite assemblages. Cladistics, 1995, 10, 155-173.

Purvis A. A composite estimate of primate phylogeny. Philosophical Transactions of the Royal Society, London, B, 1995, 348, 405-421.

REINHARD K.J. Cultural ecology of prehistoric parasitism on the Colorado Plateau as evidenced by coprology. American Journal of Physical Anthropology, 1988, 77, 355-366.

Reinhard K.J. Archaeoparasitology in North America. American Journal of Physical Anthropology, 1990, 82, 145-162.

RYANG Y.S. Enterobius vermicularis infection in school children and environmental contamination with Enterobius eggs. Korean Journal of Veterinary Public Health, 1975, 12, 108-114.

SANDOSHAM A.A. On Enterobius vermicularis (Linnaeus, 1758) and some related species from Primates and Rodents. Journal of Helmintbology, 1950, 24, 171-204.

SAMUELS R. Parasitological study of long dried fecal samples. American. Antiquity, 1965, 31, 175-179.

Seurat L.G. Sur les Oxyures de Mammifères. Comptes-rendus des Séances de la Société Biologique, Paris, 1916, 79, 6468.

Seurat L.G. Histoire naturelle des Nématódes de la Berbérie. I. Morphologie, développement et affinités des Nématodes. Imp. S. Stamel, Alger, 1920, 221 p.

Sмyth J.D. Introduction to Animal Parasitology, $3 d$ edn. Cambridge University Press, 1994, 549 p.

Zar J.H. Biostatistical Analysis, 2nd edn. Prentice-Hall, Inc., New Jersey, 1984, 718 p.

Reçu le 16 septembre 1998 Accepté le 26 avril 1999 